\title{
ANALISIS PENGARUH BUDAYA PERUSAHAAN TERHADAP KINERJA KARYAWAN PADA PT BANK TABUNGAN NEGARA (PERSERO) TBK CABANG PALEMBANG Roswaty $^{1}$
}

${ }^{1,}$ Dosen jurusan Manajemen, Universitas Indo Global Mandiri, Sumatera Selatan

${ }^{1)}$ Email : roswaty@uigm.ac.id

\section{Submitted: \\ $06 / 01 / 2021$ \\ Revised: \\ $25 / 05 / 2021$ \\ Accepted: \\ $27 / 06 / 2021$ \\ Online-Published: $30 / 06 / 2021$}

INFORMASI ARTIKEL

\begin{abstract}
ABSTRAK
Penelitian ini bertujuan untuk mengetahui, menganalisis dan membuktikan besarnya Pengaruh Budaya Perusahaan Terhadap Kinerja Karyawan pada PT. Bank Tabungan Negara (Persero) Tbk Cabang Palembang. Penelitian ini merupakan penelitian dengan jumlah sampel sebanyak 58 orang responden. Teknik pengambilan sampel yang digunakan dalam penelitian ini adalah sampel jenuh. Pada penelitian ini variabel bebasnya yaitu Budaya Perusahaan dan variabel terikatnya adalah Kinerja Karyawan. Nilai Koefisien Korelasi digunakan untuk mengetahui tingkat keeratan hubungan antara Budaya Perusahaan dan Kinerja Karyawan. Berdasarkan hasil data tersebut dapat diambil kesimpulan bahwa antara variabel Budaya Perusahaan dan variabel Kinerja Karyawan mempunyai hubungan yang sangat kuat karena memiliki nilai korelasi sebesar 0,860 (86,0\%). Dari hasil perhitungan koefisien determinasi (R2) tersebut maka dapat disimpulkan bahwa terdapat Pengaruh positif dan signifikan variabel Budaya Perusahaan Terhadap Kinerja Karyawan sebesar $74 \%$, dan sisanya sebesar $26 \%$ dipengaruhi oleh variabel independen lain yang tidak dimasukkan dalam penelitian ini.
\end{abstract}

Kata Kunci: Budaya Perusahaan, Kinerja Karyawan.

\begin{abstract}
ABSTRACK
This study aims to determine the influence of corporate culture on the performance of employees of PT. Bank Tabungan Negara (Persero) Tbk Palembang Branch. This study involves a total sample of 58 respondents. The sampling technique used in this study is a saturated sample. In this study, the independent variable is corporate culture, and the dependent variable is employee performance. The correlation coefficient number is applied to determine the relationship between company culture and employee performance. Based on the results of these data, it can be explained that between corporate culture on employee performance variables have a very strong relationship because it has a correlation value of 0.860 (86.0\%). From the calculation of the coefficient of determination (R2), it can be summarized that there is an influence of cultural variables on employee performance by $74 \%$, and the remaining $26 \%$ is influenced by other independent variables not included in this study.
\end{abstract}

Keywords: Corporate Culture, Employee Performance

\section{A. PENDAHULUAN Latar Belakang}

Suatu perusahaan dibentuk untuk mencapai tujuan bersama, namun untuk mencapai tujuan secara efektif diperlukan budaya perusahaan yang baik dan benar. Budaya merupakan perekat yang mempersatukan organisasi dengan manajemen kinerja. Manajemen kinerja merupakan gaya manajemen dalam 
mengelola sumber daya yang berorientasi pada kinerja yang melakukan proses komunikasi secara terbuka dan berkelanjutan dengan menciptakan visi bersama dan untuk mencapai tujuan organisasi (Wibowo, 2016).

Budaya perusahaan merupakan modal kerja bagi karyawan, karena nilai-nilai yang terkandung didalam budaya suatu perusahaan dapat membentuk sikap, karakteristik dan perilaku sehari-hari dalam bekerja dan bisa menjadi identitas, pembeda dari perusahaan lainnya. Karyawan adalah seorang manusia yang bekerja yang menggunakan tenaga dan kemampuannya untuk mendapatkan balasan berupa gaji/pendapatan baik berupa uang dan barang lainnya pada suatu perusahaan.

$$
\text { Kinerja karyawan sangat }
$$

berpengaruh terhadap produktivitas perusahaan karena apabila kinerja karyawan buruk maka akan berdampak buruk juga untuk perusahaan. Tujuan kinerja adalah untuk menyesuaikan harapan kinerja individual dengan tujuan organisasi. Kesesuaian antara upaya pencapaian tujuan individu dengan tujuan organisasi akan mampu mewujudkan kinerja yang baik. Terdapat beberapa faktor yang perlu diperhatikan untuk suatu organisai mempunyai kinerja yang baik, yaitu menyangkut pernyataan tentang maksud dan nilai-nilai, manajeman strategis, manajemen sumber daya manusia, pengembangan organisasi, konteks organisasi, desain kerja, fungsionalisme, budaya dan kerja sama (Wibowo, 2016).

Bank BTN telah membuat sebuah budaya perusahaan yang mempunyai makna, mengandung lima nilai budaya perusahaan yang diwajibkan bagi karyawan untuk menghafal, memahami, dan menerapkannya dalam berperilaku yaitu SIIPS (Sinergi, Integritas, Inovasi, Profesionalisme, dan Spirit Mencapai Keunggulan) sehingga dapat berpengaruh terhadap kinerja karyawan. Hubungan antara budaya perusahaan terhadap kinerja karyawan sendiri menjadi faktor penting dalam suatu perusahaan agar mempunyai kinerja yang baik, untuk melihat pengaruh dari budaya organisasi terhadap kinerja karyawan perlu dilakukan penelitian lebih lanjut.

Berdasarkan penelitian yang telah dilakukan oleh (Mulyadi, Sulaeman, dan
Ramdhani, 2012) pengaruh budaya organisasi terhadap Kinerja Pegawai memiliki hubungan yang kuat, hal ini dibuktikan berdasarkan hasil analisis mengenai pengaruh budaya organisasi terhadap kinerja Pegawai Dinas Bina Marga dan Pengairan Kabupaten Karawang memiliki nilai korelasi sebesar 0,607 yang berarti memiliki hubungan kuat. Berdasarkan latar belakang yang telah diuraikan diatas, maka penulis tertarik untuk mengangkat judul" Pengaruh Budaya Perusahaan Terhadap Kinerja Karyawan PT. Bank Tabungan Negara (Persero) Tbk Cabang Palembang".

Berdasarkan uraian diatas, maka penulis tertarik untuk melakukan penelitian dengan judul: "Analisis Pengaruh Budaya Perusahaan Terhadap Kinerja Karyawan pada PT. Bank Tabungan Negara (Persero) Tbk Cabang Palembang".

\section{Masalah Penelitian}

Berdasarkan latar belakang yang telah diuraikan diatas, maka penulis merumuskan masalahnya adalah "Bagaimana Pengaruh Budaya Perusahaan Terhadap Kinerja Karyawan pada PT. Bank Tabungan Negara (Persero) Tbk Cabang Palembang?”.

\section{Tujuan Penelitian}

Adapun tujuan penelitian ini adalah untuk mengetahui, menganalisis dan membuktikan Pengaruh Budaya Perusahaan Terhadap Kinerja Karyawan pada PT. Bank Tabungan Negara (Persero) Tbk Cabang Palembang.

\section{Hipotesis Penelitian}

Hipotesis dalam penelitian ini adalah

- Diduga Terdapat Pengaruh Budaya Perusahaan Terhadap Kinerja Karyawan pada PT. Bank Tabungan Negara (Persero) Tbk Cabang Palembang.

\section{Tinjauan Pustaka}

Menurut Wibowo (2016) budaya merupakan perekat yang mempersatukan organisasi dengan manajemen kinerja. Filosofi dan desain tidak terelakkan dipengaruhi oleh budaya organisasi yang berlaku. Menurut Ganyang (2018) organisasi adalah kerjasama antar dua orang atau lebih 
untuk mencapai tujuan bersama. Menurut Torang (2016) organisasi dikoordinasikan secara sadar mengandung arti manajemen dan organisasi yang merupakan entitas (kesatuan) sosial berarti bahwa unit itu terdiri dari orang atau kelompok orang yang saling berinteraksi. Dengan demikian, dalam berbagai hal dapat dikatakan bahwa kelompok adalah bagian dari organisasi.

$$
\text { Menurut Sedarmayanti }
$$

budaya organisasi adalah sebuah keyakinan, sikap, dan nilai yang umumnya dimiliki, yang timbul dalam organisasi, dikemukakan dengan lebih sederhana. Budaya adalah cara kita melakukan sesuatu. Pola nilai, norma, keyakinan, sikap, dan asumsi ini mungkin tidak diungkapkan, tetapi akan membentuk cara orang berperilaku dan melakukan sesuatu. Menurut Ganyang (2018) artefak budaya organisasi adalah bagian dari budaya organisasi yang paling mudah diamati baik oleh anggota organisasi maupun oleh pihak luar karena dapat dilihat, didengar, dirasa, dikenakan, dan dinikmati. Artefak budaya organisasi terdiri dari beberapa unsur yaitu logo organisasi, bendera organisasi, seragam, nyanyian dan slogan. Menurut Wibowo (2016) kinerja berasal dari pengertian performance. Ada pula yang memberikan pengertian performance sebagai hasil kerja atau prestasi kerja.

\section{Menurut Torang}

mengungkapkan proses budaya organisasi dapat dipandang dari terbentuknya/terciptanya, dipertahankan/ dipeliharanya, dan diubah / dikembangkannya budaya organisasi, sedangkan untuk menghadapi tantangan perubahan budaya, diperlukan adaptasi proses budaya. Ada 5 kekuatan yang dapat membentuk dan mempertahankan budaya organisasi, yaitu peran pimpinan, selektif (proses recruitment terhadap orang-orang yang dapat dipanuti), sosialiasi, pengembangan budaya organisasi ( melalui perubahan sistem struktur, proses/system, Sumber daya manusia (SDM)), adaptasi. Desakan lingkungan sosial, ekonomi, dan politik terhadap perubahan budaya organisasi merupakan suatu keharusan yang tidak dapat dihindari.

Menurut Kroeber \& Kluckhohn dalam (Susanto,2018) terdapat beberapa indikator budaya, salah satunya sinergi budaya yang kuat yang dipegang para anggota akan ditunjukkan dengan kesepakatan yang kuat pula untuk bersinergi dalam mencapai tujuan organisasi, berlaku dan bertindak sesuai aturan. Menurut Susanto dan Aisyah (2010) menjelaskan beberapa indikator antara lain adalah kreatif, ketekunan, kerjasama, integritas, dan rasionalitas. Menurut Jerome want dalam (Wibowo, 2018) menjelaskan bahwa terdapat beberapa indikator budaya perusahaan, yaitu misi dan strategi, efektivitas kepemimpinan dan manajemen, komunikasi dan pengambilan keputusan, desain dan struktur organisasi, perilaku, organisasi, pengetahuan dan kompetensi, intervensi bisnis dan organisasi, dan inovasi dan pengambilan keputusan. Inovasi dan pengambilan risiko menjadi komoditas langka dalam bisnis. Kecenderungan mengarah pada peningkatan kebutuhan akan pengawasan oleh manajemen. Peluang untuk inovasi dan pengambilan risiko harus menjadi komponen utama dalam setiap budaya. Menurut Sobirin (2019) menjelaskan bahwa terdapat beberapa indikator budaya yaitu formalisasi organisasi, spesialisasi, standarisasi kerja, hirarki organisasi, kompleksitas organisasi, sentralisasi dan profesionalisme. Profesionalisme adalah tingkat pendidikan formal dan latihan-latihan khusus yang harus dimiliki karyawan untuk suatu posisi jabatan tertentu. Dan menurut Syarif dan Anggriyani dalam (Atmadja, 2018) menyatakan bahwa kualitas kehidupan organisasi, baik yang terwujud dalam kebiasaan kepemimpinan dan hubungan tersebut tumbuh dan berkembang berdasarkan spirit.

Menurut Wibowo (2016) kinerja berasal dari pengertian performance. Ada pula yang memberikan pengertian performance sebagai hasil kerja atau prestasi kerja. Namun, sebenarnya kinerja mempunyai makna yang lebih luas, bukan hanya hasil kerja, tetapi termasuk bagaimana proses pekerjaan berlangsung. Dengan demikian, kinerja adalah tentang melakukan pekerjaan dan hasil yang dicapai dari pekerjaan tersebut. Menurut Wibowo (2016) sasaran kinerja merupakan suatu pernyataan secara spesifik yang menjelaskan hasil yang harus dicapai, kapan, dan oleh siapa sasaran yang ingin dicapai tersebut diselesaikan. 
Menurut Bintoro dan Daryanto (2017) mengemukakan indikator-indikator kinerja karyawan yaitu sebagai berikut :

1.Kualitas kerja adalah kualitas kerja yang dicapai berdasarkan syarat-syarat kesesuaian dan kesiapannya yang tinggi pada gilirannya akan melahirkan penghargaan dan kemajuan serta pengembangan organisasi melalui peningkatan pengetahuan dan keterampilan secara sistematis sesuai tuntutan ilmu pengetahuan dan teknologi yang semakin berkembang pesat.

2.Ketetapan waktu yaitu berkaitan dengan sesuai atau tidaknya waktu penyelesaian pekerjaan dengan target waktu yang direncanakan. Setiap pekerjaan diusahakan selesai sesuai dengan rencana agar tidak menganggu pada pekerjaan yang lain.

3.Komunikasi merupakan interaksi yang dilakukan oleh atasan kepada bawahan untuk mengemukakan saran dan pendapatnya dalam memecahkan masalah yang dihadapi. Terjadi hubungan-hubungan yang semakin harmonis diantara para pegawai dan para atasan, yang juga dapat menimbulkan perasaan senasib sepenanggungan.

\section{B. METODE PENELITIAN}

Penelitian ini akan membahas masalah yang berkaitan dengan pengaruh budaya perusahaan terhadap kinerja karyawan pada PT. Bank Tabungan Negara (Persero) Tbk (Bank BTN) Cabang Palembang. Apakah budaya perusahaan berpengaruh terhadap kinerja karyawan secara signifikan dalam perusahaan. Adapun objek penelitian ini yaitu : pengaruh budaya perusahaan terhadap kinerja karyawan pada PT. Bank Tabungan Negara (Persero) Tbk Cabang Palembang. Penelitian ini akan dilakukan di PT. Bank Tabungan Negara (Persero) Tbk Cabang Palembang, bertempat di Jalan Jendral Sudirman KM. 4.5 NO.125 Palembang. Waktu penelitian ini di rencanakan akan dilakukan pada bulan September 2019 sampai Januari 2020. Berdasarkan identifikasi masalah yang dipaparkan sebelumnya, supaya penelitian ini lebih fokus tidak meluas dari pembahasan yang dimaksud maka dalam penelitian ini, penulis membatasi permasalahan yang dikaji pada ruang lingkup pengaruh budaya perusahaan terhadap kinerja karyawan pada
PT. Bank Tabungan Negara (Persero) Tbk Cabang Palembang.

\section{A. Jenis Data}

Jenis data dibagi menjadi 2 yaitu 1 . Data Kualitatif, menurut Sujarweni (2018) Penelitian kualitatif secara umum dapat digunakan untuk penelitian tentang kehidupan masyarakat, sejarah, tingkah laku, fungsionalisasi, organisasi, aktivitas sosial dan lain-lain. Pendekatan kualitatif diharapkan mampu menghasilkan uraian yang mendalam tentang ucapan, tulisan, dan atau perilaku yang dapat diamati dari suatu individu, kelompok, masyarakat, dan atau organisasi tertentu dalam suatu keadaan konteks tertentu. 2. Data Kuantitatif, menurut Sujarweni (2018) penelitian kuantitatif adalah jenis penelitian yang menghasilkan penemuan-penemuan yang dapat dicapai dengan menggunakan prosedur-prosedur Statistical Product and Service Solutions (SPSS) atau cara lain dari kuantifikasi (pengukuran). Dalam pendekatan kuantitatif hakekat hubungan diantara variabel-variabel dianalisis dengan menggunakan teori yang obyektif.

\section{B. Sumber Data}

Pada penelitian ini menggunakan dua jenis sumber data yaitu data primer yang diperoleh dari responden melalui pembagian kuesioner kepada karyawan Bank BTN Kantor Cabang Palembang dan data sekunder yang diperoleh dari website Bank BTN, catatan, buku, majalah berupa laporan, artikel, dan lain sebagainya.

\section{Populasi dan Sampel}

Pada penelitian ini, populasi adalah semua karyawan tetap PT. Bank Tabungan Negara (Persero) Tbk Cabang Palembang sebanyak 137 orang karyawan. Menurut Sujarweni sampel (2018) adalah bagian dari sejumlah karakteristik yang dimiliki oleh populasi yang digunakan untuk penelitian. Bila populasi besar, peneliti tidak mungkin mengambil semua untuk penelitian misal karena terbatasnya dana, tenaga, dan waktu, maka penelitian dapat menggunakan sampel yang diambil dari populasi itu. Apa yang dipelajari dari sampel, kesimpulannya akan dapat diberlakukan untuk populasi. Untuk itu sampel yang diambil dari populasi harus 
betul-betul mewakili dan harus valid, yaitu bisa mengukur sesuatu yang seharusnya diukur. Ukuran sampel atau jumlah sampel yang diambil merupakan hal yang penting jika peneliti melakukan penelitian yang menggunakan analisis kuantitatif. Untuk menentukan ukuran sampel dapat menggunakan rumus slovin. Populasi responden adalah seluruh pegawai Bank BTN berjumlah 137 orang, maka sampel yang diambil sebagai penelitian jika menggunakan rumus slovin dengan tingkat kepercayaan 90 $\%$, dan tingkat error $10 \%$ adalah $\mathrm{n}=57,8$ ( 58 sampel ) sebagai berikut :



Menurut Sujarweni (2018) untuk menentukan sampel yang akan digunakan dalam penelitian, terdapat teknik sampling yang digunakan yaitu berkategori probability sampling (setiap individu yang terdapat dalam populasi dapat dijadikan sampel). Probability sampling adalah teknik pengambilan sampel yang memberikan peluang yang sama bagi setiap unsur (anggota) populasi untuk dipilih menjadi anggota sampel. Menurut Sujarweni (2018) analisis data dapat diartikan sebagai upaya data yang sudah tersedia kemudian diolah dengan Statistical Product and Service Solutions ( SPSS ) dan dapat digunakan untuk menjawab rumusan masalah dalam penelitian. Dengan demikian, teknik analisis data dapat diartikan sebagai cara melaksanakan analisis terhadap data, dengan tujuan mengolah data tersebut untuk menjawab rumusan masalah.

\section{Teknik Pengumpulan Data}

Menurut Sujarweni (2018) teknik pengumpulan data merupakan cara yang dilakukan peneliti untuk mengungkap atau menjaring informasi dari responden sesuai lingkup penelitian. ada beberapa teknik pengumpulan data penelitian yang biasa digunakan adalah observasi, wawancara, studi dokumen, dan kuesioner atau angket. Pada teknik pengumpulan data penelitian yang digunakan adalah Kuesioner atau Angket yang dibagikan kepada seluruh karyawan Bank BTN dan Studi dokumen yang berbentuk data tersimpan di website, dan lain-lain.

\section{E. Teknik Analisis}

Menurut Sujarweni (2018) data yang diperoleh dari kuesioner kemudian dilakukan uji validitas dengan melihat korelasi antar item pertanyaan. Uji validitas digunakan untuk mengetahui kelayakan butir-butir dalam suatu daftar pertanyaan dalam mendefinisikan suatu variabel. Validitas suatu instrumen menurutnya menunjukkan seberapa jauh ia dapat mengukur apa yang hendak diukur. Daftar pertanyaan ini pada umumnya mendukung suatu kelompok variable tertentu. Hasil $r$ hitung kita bandingkan dengan $r$ tabel dimana $\mathrm{df}-=\mathrm{n}-2$ dengan sig $5 \%$. Jika $r$ tabel $<r$ hitung maka valid.

Menurut Sujarweni (2018) data untuk mengukur suatu kuesioner yang merupakan indikator dari variabel atau konstruk. Uji reliabilitas merupakan suatu ukuran kestabilan dan konsistensi responden dalam menjawab hal yang berkaitan dengan kontruk-kontruk pertanyaan yang merupakan dimensi suatu variabel dan disusun dalam suatu bentuk kuesioner. Secara internal, pengujian dilakukan dengan menganalisis konsistensi butir-butir yang ada pada instrumen dengan teknik-teknik tertentu. Uji reliabilitas dapat dilakukan secara bersamasama terhadap seluruh butir pertanyaan, jika nilai Alpha > 0,60 maka reliabel, menunjukkan tingkat konsistensi dan akurasi hasil pengukuran.

Menurut Siregar (2017) data yang berdistribusi normal artinya data yang mempunyai sebaran yang normal, dengan profil yang dapat dikatakan bisa mewakili populasi. Uji normalitas adalah uji untuk mengukur apakah data kita memiliki distribusi normal sehingga dapat dipakai dalam statistik parametrik, jika data tidak berdistribusi dapat dipakai statistik non parametrik.

Menurut Siregar (2017) dalam melakukan pengujian hipotesis dengan menggunakan uji statistik dapat digunakan uji t untuk menguji hipotesisnya. Hipotesis merupakan jawaban sementara terhadap tujuan penelitian yang diturunkan dari kerangka pemikiran yang telah dibuat. Hipotesis merupakan pernyataan tentatif 
tentang hubungan antara dua variabel atau lebih. Hipotesis merupakan dugaan sementara dari jawaban rumusan masalah penelitian.

Menurut Siregar (2017) regresi linier sederhana terdiri dari satu variabel dependen (terikat) dan satu variabel independen (bebas). Menurut Siregar (2017) koefisien korelasi adalah bilangan yang menyatakan kekuatan hubungan antara dua variabel atau lebih atau juga dapat menentukan arah dari kedua variabel. Nilai korelasi $(-1 \leq 0 \leq 1)$. Untuk kekuatan hubungan, nilai koefisien korelasi berada diantara -1 dan 1 , sedangkan untuk arah dinyatakan dalam bentuk positif (+) dan negatif (-).

Tabel 1. Koefisien Korelasi dan Kekuatan Hubungan

\begin{tabular}{|l|l|}
\hline Nilai Korelasi (r) & Tingkat Hubungan \\
\hline $0,00-0,199$ & Sangat lemah \\
\hline $0,20-0,399$ & Lemah \\
\hline $0,40-0,599$ & Sedang \\
\hline $0,60-0,799$ & Kuat \\
\hline $0,80-0,100$ & Sangat Kuat \\
\hline
\end{tabular}

Sumber : Siregar (2017)

Menurut Siregar (2017) Koefisien Determinasi $\left(\mathrm{R}^{2}\right)$ adalah angka yang menyatakan atau digunakan untuk mengetahui besarnya kontribusi atau sumbangan yang diberikan oleh sebuah atau lebih variabel bebas (X) terhadap variabel terikat (Y). Menurut Sujarweni (2018) operasional adalah variabel penelitian yang dimaksudkan untuk memahami arti setiap variabel penelitian sebelum dilakukan analisis.

Menurut Sujarweni (2018) variabel penelitian adalah sebagai atribut seseorang atau objek yang mempunyai variasi satu orang dengan yang lain, atau satu objek dengan objek yang lain. Adapun jenis-jenis variabel tersebut adalah variabel independen adalah Budaya Perusahaan (X) dan variabel dependen yaitu Kinerja Karyawan ( Y ).

\section{HASIL DAN PEMBAHASAN}

Berdasarkan teknik pengambilan sampel dan kuesioner yang dibagikan kepada responden, berikut ini akan dilakukan rangkaian penjelasan yang bertujuan untuk membahas masalah penelitian dan menjawab tujuan dari dilakukannya penelitian ini. Responden merupakan sampel dari populasi karyawan pada PT. Bank Tabungan Negara (Persero) Tbk Cabang Palembang berjumlah 58 orang.

Sebelum dilakukan pembahasan lebih lanjut mengenai Pengaruh Budaya Perusahaan Terhadap Kinerja Karyawan pada PT.Bank Tabungan Negara (Persero) Tbk Cabang Palembang, terlebih dahulu akan dilaksanakan beberapa pengujian yaitu uji karakteristik responden, validitas, reliabilitas, normalitas, uji t statistik, Analisis Regresi Linear Sederhana, Koefisien Korelasi (R) dan Koefisien Determinasi (R square)

Skala pengukuran instrumen penelitian yang digunakan pada penelitian ini adalah Skala likert. Menurut Siregar (2017) Skala likert adalah skala yang digunakan untuk mengukur sikap, pendapat, dan persepsi seseorang tentang suatu objek atau fenomena tertentu. Bentuk jawaban Skala likert terdiri dari Sangat Setuju, Setuju, Netral, Tidak Setuju, dan Sangat Tidak Setuju.

\section{A. Karakteristik Responden}

yaitu karakteristik responden bedasarkan Jenis Kelamin, adapun responden yang diteliti bedasarkan jenis kelamin dapat dilihat pada tabel dan gambar berikut:

\section{Tabel 2. Responden Bedasarkan Jenis Kelamin}


Jenis Kelamin

\begin{tabular}{|c|r|r|r|r|}
\hline & Frequency & Percent & Valid Percent & Cumulative Percent \\
\hline Valid LAKI-LAKI & 20 & 34,5 & 34,5 & 34,5 \\
PEREMPUAN & 38 & 65,5 & 65,5 & 100,0 \\
Total & 58 & 100,0 & 100,0 & \\
\hline
\end{tabular}

Sumber : hasil pengolahan dengan IMB SPSS version 23

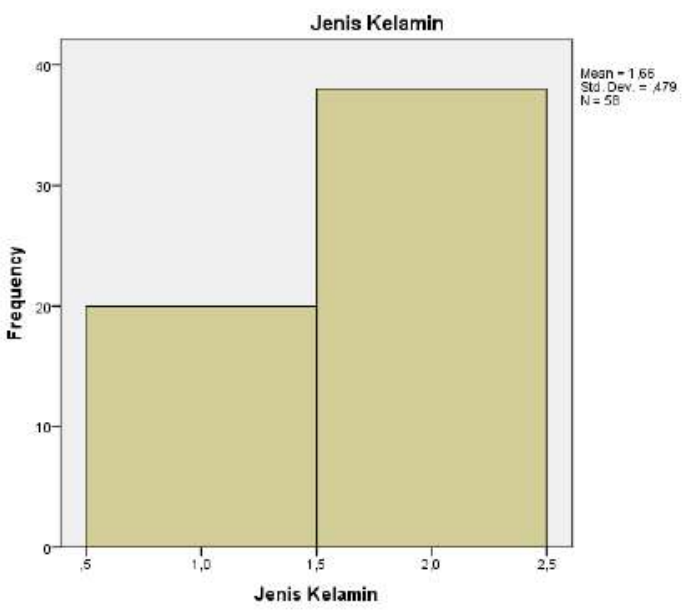

. Gambar 1. Responden Bedasarkan Jenis Kelamin
Berdasarkan hasil pengolahan data dengan spss pada tabel 2 menunjukkan bahwa data yang diperoleh dari responden adalah laki-laki sebanyak 20 orang, dan perempuan sebanyak 38 orang.

\section{B. Pengujian Validitas}

Hasil $r$ hitung kita bandingkan dengan $r$ tabel dimana $\mathrm{df}-\mathrm{=}-\mathrm{n}-2(58-2)=56$ responden dengan sig 5\%. Jika $r$ tabel $<\mathrm{r}$ hitung maka valid.

Tabel 3. Hasil Uji Validitas Variabel Budaya (X)

Sumber : hasil pengolahan dengan IMB

SPSS version 23

\begin{tabular}{|l|c|c|c|}
\hline \multicolumn{1}{|c|}{ ITEM } & $\mathbf{R}_{\text {Hitung }}$ & $\mathbf{R}_{\text {Tabel }}$ & KETERANGAN \\
\hline Budaya 1 & 0,721 & 0.258 & Valid \\
\hline Budaya 2 & 0,798 & 0.258 & Valid \\
\hline Budaya 3 & 0,765 & 0,258 & Valid \\
\hline Budaya 4 & 0,769 & 0.258 & Valid \\
\hline Budaya 5 & 0,798 & 0.258 & Valid \\
\hline Budaya 6 & 0,712 & 0,258 & Valid \\
\hline Budaya 7 & 0,843 & 0,258 & Valid \\
\hline Budaya 8 & 0,802 & 0,258 & Valid \\
\hline Budaya 9 & 0,759 & 0,258 & Valid \\
\hline Budaya 10 & 0,808 & 0,258 & Valid \\
\hline Budaya 11 & 0,665 & 0,258 & Valid \\
\hline Budaya 12 & 0,721 & 0,258 & Valid \\
\hline Budaya 13 & 0,853 & 0,258 & Valid \\
\hline Budaya 14 & 0,846 & 0,258 & Valid \\
\hline Budaya 15 & 0,720 & 0,258 & Valid \\
\hline
\end{tabular}

Sumber : hasil pengolahan dengan IBM

SPSS version 23 


\section{Tabel 4. Hasil Uji Validitas Variabel}

Kinerja (Y)

\begin{tabular}{|c|c|c|c|}
\hline ITEM & $\mathbf{R}_{\text {Hitung }}$ & $\mathbf{R}_{\text {Tabel }}$ & KETERANGAN \\
\hline Kinerja 1 & 0,817 & 0,258 & Valid \\
\hline Kinerja 2 & 0,873 & 0,258 & Valid \\
\hline Kinerja 3 & 0,815 & 0,258 & Valid \\
\hline Kinerja 4 & 0,306 & 0,258 & Valid \\
\hline Kinerja 5 & 0,761 & 0,258 & Valid \\
\hline Kinerja 6 & 0,705 & 0,258 & Valid \\
\hline Kinerja 7 & 0,803 & 0,258 & Valid \\
\hline Kinerja 8 & 0,869 & 0,258 & Valid \\
\hline Kinerja 9 & 0,851 & 0,258 & Valid \\
\hline
\end{tabular}

Sumber : hasil pengolahan dengan IBM

SPSS version 23

Berdasarkan hasil data pada kedua table 3 dan 4 diatas terlihat bahwa hasil uji validitas data menunjukkan semua butir pertanyaan valid, karena RHitung lebih besar dari $\mathrm{RTabel}=0,258$.

\section{Pengujian Reliabilitas}

Berdasarkan hasil uji reliabilitas tersebut menunjukkan semua variabel mempunyai koefisien alpha yang cukup besar yaitu diatas 0.6 yaitu 0,958 dengan $\mathrm{N}$ jumlah pertanyaan 15 butir dan 0,879 dengan $\mathrm{N}$ jumlah pertanyaan 9 butir bahwa semua konsep pengukur masing-masing variabel dari kuesioner reliabilitas sehingga dapat dikatakan kestabilan dan konsistensi responden dalam menjawab hal yang berkaitan dengan kontruk-kontruk pertanyaan yang disusun dalam suatu bentuk kuesioner layak digunakan sebagai alat ukur.

Tabel 5. Hasil Uji reliabilitas

\begin{tabular}{|c|c|c|c|}
\hline Variabel & $\begin{array}{c}\text { Cronchbach's } \\
\text { Alpha }\end{array}$ & $\begin{array}{c}\text { Ketentuan } \\
\mathbf{R}_{\text {tabel }}\end{array}$ & Hasil \\
\hline Budaya & 0.958 & 0.6 & Reliabel \\
\hline Kinerja & 0.879 & 0.6 & Reliabel \\
\hline
\end{tabular}

Sumber : hasil pengolahan dengan IBM SPSS version 23

Berdasarkan hasil data dari tabel 5 diatas menunjukkan bahwa data yang diperoleh dari responden dikatakan reliable, dikarenakan nilai Alpha >0,60.

\section{Pengujian Normalitas}

Menurut Siregar (2017) data yang berdistribusi normal artinya data yang mempunyai sebaran yang normal, dengan profil yang dapat dikatakan bisa mewakili populasi. Uji normalitas adalah uji untuk mengukur apakah data kita memiliki distribusi normal sehingga dapat dipakai dalam statistik parametrik, jika data tidak berdistribusi dapat dipakai statistik non
parametrik.N Histogram dimana berupa tampilan bentuk grafis untuk menunjukan distribusi data secara visual atau seberapa sering suatu nilai yang berbeda itu sering terjadi dalam suatu kumpulan data.

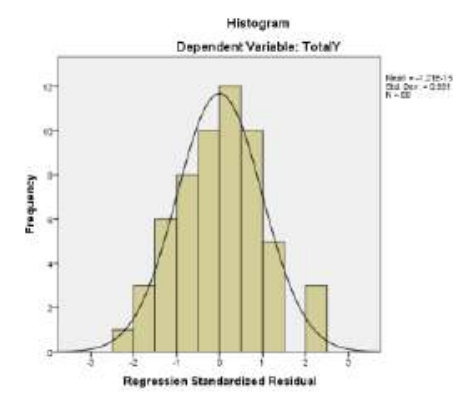

Gambar 2. Hasil Uji Normalitas Histogram 
Sumber : hasil pengolahan dengan

IBM SPSS version 23

Dari gambar 2 dapat diketahui bahwa grafik membentuk gunung atau lonceng, maka dengan ini data residual terdistribusi secara normal.

\section{E. Pengujian t statistik}

Uji statistik $t$ dimana untuk mengetahui apakah variabel bebas berpengaruh secara singnifikan terhadap variabel terkait. Serta untuk menguji pengaruh masing-masing variabel bebas yang digunakan dalam penelitian ini secara parsial digunakan uji t dengan tingkat signifikan sebesar $5 \% \quad(\alpha=0,05)$. Berdasarkan penelitian uji statistik diperoleh hasil perhitungan diketahui bahwa nilai sig $0,000<0,05$ hal ini berarti Ho ditolak dan H1 diterima, sehingga dapat disimpulkan bahwa budaya berpengaruh positif secara singnifikan terhadap kinerja karyawan.

Tabel 6. Menguji Signifikan Variabel Budaya (X)

\section{Coefficients $^{\mathrm{a}}$}

\begin{tabular}{|l|r|r|r|r|r|}
\hline \multirow{2}{*}{ Model } & \multicolumn{2}{|c|}{$\begin{array}{c}\text { Unstandardized } \\
\text { Coefficients }\end{array}$} & $\begin{array}{c}\text { Standardize } \\
\mathrm{d} \\
\text { Coefficients }\end{array}$ & & \multirow{2}{*}{ Sig. } \\
\cline { 2 - 4 } & $\mathrm{B}$ & Std. Error & Beta & $\mathrm{T}$ &, 229 \\
TotalX & 3,394 & 2,793 & & 1,215 &, 000 \\
\hline
\end{tabular}

a. Dependent Variable: TotalY

Sumber : hasil pengolahan dengan IBM SPSS version 23

Dari hasil perhitungan diatas diketahui bahwa nilai t-hitung $(12,613)>\mathrm{t}$ tabel $(2,00324)$ dan sig $0,000<0,05$ hal ini berarti Ho di tolak dan H1 diterima, sehingga dapat disimpulkan bahwa budaya berpengaruh secara signifikan terhadap kinerja karyawan. Dari penjelasan tersebut dapat menunjukkan bahwa variabel independen (Budaya) berpengaruh secara positif dan signifikan terhadap variabel dependen (Kinerja). Hal ini ditunjukkan dengan uji t yang memiliki nilai signifikansi lebih kecil dari 0,05 yaitu sebesar 0,000. Dapat disimpulkan berdasarkan nilai hasil output spsss bahwa budaya berpengaruh secara positif dan signifikan terhadap kinerja karyawan pada PT. Bank Tabungan Negara (Persero) Tbk Cabang Palembang.

\section{F. Pengujian Regresi Linier Sederhana}

Persamaan regresi tersebut jika di masukkan ke dalam persamaan regresi $\mathrm{Y}=\mathrm{a}+\mathrm{bX}$ dapat dijelaskan sebagai berikut : Hasil uji regresi sederhana menunjukkan konstanta $a=3,394$ dan koefisien $b=0,559$. Sehingga persamaan regresi linier sederhana menjadi $\mathrm{Y}=3,394+0,559 \mathrm{X}$.

\section{Tabel 7. Hasil Uji Regresi Linier} Sederhana 


\section{Coefficients $^{\mathbf{a}}$}

\begin{tabular}{|c|c|c|c|c|c|}
\hline \multirow[b]{2}{*}{ Model } & \multicolumn{2}{|c|}{$\begin{array}{l}\text { Unstandardized } \\
\text { Coefficients }\end{array}$} & \multirow{2}{*}{\begin{tabular}{|c|}
$\begin{array}{c}\text { Standardize } \\
\mathrm{d} \\
\text { Coefficients }\end{array}$ \\
Beta \\
\end{tabular}} & \multirow[b]{2}{*}{$\mathrm{T}$} & \multirow[b]{2}{*}{ Sig. } \\
\hline & B & Std. Error & & & \\
\hline $\begin{array}{ll}1 \quad \text { (Constan } \\
\text { t) }\end{array}$ & 3,394 & 2,793 & & 1,215 & ,229 \\
\hline TotalX & ,559 & ,044 &, 860 & 12,613 & ,000 \\
\hline
\end{tabular}

a. Dependent Variable: TotalY

Sumber : hasil pengolahan dengan IBM SPSS version 23
Tabel 8.

Koefisien Korelasi $(R)$ \& Koefisien Determinasi (R Square)

Hasil perhitungan yang di dapat dari hasil pengolahan data SPSS yaitu koefisien regresi $(\mathrm{X})$ variabel budaya mempunyai arah koefisien regresi positif dengan variabel kinerja karyawan yaitu $b=0,559$, menyatakan bahwa setiap variabel budaya mengalami peningkatan sebesar 1 maka variabel kinerja akan mengalami peningkatan sebesar 0,559. Nilai koefisien regresi yang menunjukkan pengaruh budaya perusahaan terhadap kinerja karyawan PT. Bank Tabungan Negara (Persero) Tbk Cabang Palembang yang bertanda positif, hal ini disebabkan karena semakin baik budaya di perusahaan maka akan semakin baik juga kinerja karyawan.

\section{G. Pengujian Koefisien Korelasi (R)}

Pada tabel 8 diketahui bahwa responden sebanyak 58 dihasilkan nilai korelasi sebesar 0,860 untuk melakukan interprestasi kekuatan hubungan antara dua variabel dilakukan dengan melihat angka koefisien korelasi dari hasil perhitungan dengan menggunakan tingkat korelasi dan kekuatan hubungan pada tabel 1 .

\section{Model Summary ${ }^{\mathrm{b}}$}

\begin{tabular}{|l|r|r|r|r|}
\hline Model & $\mathrm{R}$ & \multicolumn{1}{|c|}{$\mathrm{R}$} \\
Square & $\begin{array}{c}\text { Adjusted R } \\
\text { Square }\end{array}$ & $\begin{array}{r}\text { Std. Error of } \\
\text { the Estimate }\end{array}$ \\
\hline 1 &, $860^{\mathrm{a}}$ &, 740 &, 735 & 2,828 \\
\hline
\end{tabular}

a. Predictors: (Constant), TotalX

b. Dependent Variable: TotalY

\section{Sumber : hasil pengolahan dengan IBM} SPSS version 23

Berdasarkan hasil data tabel 1 tingkat korelasi dan kekuatan hubungan tersebut dapat diambil kesimpulan bahwa antara variabel budaya terhadap varibel kinerja karyawan, mempunyai hubungan yang sangat kuat karena memiliki nilai korelasi sebesar $0,860(86,0 \%)$.

\section{H. Pengujian Koefisien Determinasi $\left(\mathbf{R}^{2}\right)$}

Untuk mengetahui seberapa besar pengaruh $\mathrm{X}$ terhadap variabel $\mathrm{Y}$ dengan menggunakan koefisien determinasi $\left(\mathrm{R}^{2}\right)$ yang dinyatakan dalam persentase pada tabel 
8 R square. Berdasarkan hasil data pada tabel 7 tersebut dapat diambil kesimpulan adalah sebagai berikut :

$$
\begin{gathered}
\mathrm{R} 2=0,740 \times 100 \% \\
=74 \%
\end{gathered}
$$

Dari hasil perhitungan $\mathrm{R}^{2}$ tersebut maka dapat disimpulkan bahwa ada pengaruh variabel budaya terhadap kinerja karyawan sebesar $74 \%$, selebihnya $26 \%$ dipengaruhi oleh variabel independent yang tidak dimasukkan dalam penelitian ini.

\section{SIMPULAN DAN SARAN}

\section{Simpulan}

Berdasarkan hasil penelitian dan pembahasan pada bab-bab sebelumnya, maka dapat dibuat kesimpulan sebagai berikut :

1. Dari hasil perhitungan diatas diketahui bahwa nilai t-hitung $(12,613)>\mathrm{t}$-tabel $(2,00324)$ dan sig $0,000<0,05$ hal ini berarti Ho di tolak dan $\mathrm{H} 1$ diterima, sehingga dapat disimpulkan bahwa budaya berpengaruh secara signifikan terhadap kinerja karyawan. Dari penjelasan tersebut dapat menunjukkan bahwa variabel independen (budaya) berpengaruh secara positif dan signifikan terhadap variabel dependen (Kinerja).

2. Hasil uji regresi sederhana menunjukkan konstanta $a=3,394$ dan koefisien $\mathrm{b}=0,559$. Sehingga persamaan regresi linier sederhana menjadi $\mathrm{Y}=$ 3,394+0,559X. Konstanta (a) sebesar 3,394 menyatakan bahwa jika tidak ada nilai variabel budaya $(X=0)$, maka nilai variabel kinerja sebesar 3,394. Variabel budaya mempunyai arah koefisien regresi positif dengan variabel kinerja karyawan yaitu $b=0,559$, menyatakan bahwa setiap variabel budaya mengalami peningkatan sebesar 1 maka variabel kinerja akan mengalami peningkatan sebesar 0,559.

3. Untuk melakukan interprestasi kekuatan hubungan antara dua variabel dilakukan dengan melihat angka koefisien korelasi dari hasil perhitungan dengan menggunakan tingkat korelasi dan kekuatan hubungan. Berdasarkan hasil data pada tabel 4.12 tersebut dapat diambil kesimpulan bahwa antara variabel budaya terhadap variabel kinerja karyawan, mempunyai hubungan yang sangat kuat karena memiliki nilai korelasi sebesar 0,860 (86,0\%).

4. Berdasarkan hasil perhitungan R2 pada data tabel 4.14 tersebut dapat disimpulkan bahwa ada pengaruh variabel budaya terhadap kinerja karyawan sebesar $74 \%$, selebihnya $26 \%$ dipengaruhi oleh variabel independent yang tidak dimasukkan dalam penelitian ini.

5. Pengaruh budaya bernilai positif atau baik, artinya pada budaya perusahaan dari tiap-tiap indikator yang tepat dan baik menjadi penyebab meningkatnya kinerja karyawan PT. Bank Tabungan Negara (Persero) Tbk Cabang Palembang.

6. Secara umum hasil penelitian Pengaruh Budaya Perusahaan Terhadap Kinerja Karyawan pada PT. Bank Tabungan Negara (Persero) Tbk Cabang Palembang adalah meningkat secara Positif dan Signifikan dibandingkan tahun - tahun sebelumnya.

\section{Saran}

Berdasarkan kesimpulan di atas, dapat dikemukakan beberapa saran sebagai berikut:

1. Diharapkan pihak perusahaan dapat mempertahankan pengelolaan budaya perusahaan dan lebih dikembangkan serta meningkatkan lagi budaya yang ada sehingga kinerja karyawan dapat lebih meningkat. Sedangkan untuk menghadapi tantangan perubahan budaya, diperlukan adaptasi proses budaya.

Saran bagi peneliti selanjutnya diharapkan hasil penelitian ini dapat dipakai sebagai referensi bagi peneliti selanjutnya untuk mengembangkan penelitian ini dengan menambah wawasan tentang variabel apa saja yang mempengaruhi kinerja karyawan .

\section{E. DAFTAR RUJUKAN}

Ariyanto, Maatpono and Abdul Razak Munir, (2017). Pengaruh Budaya Organisasi, Motivasi, dan Komitmen Organisasi Terhadap Kinerja Pegawai. Sulawesi Selatan). Hasanuddin journal of 
Business Strategy (HJBS). Vol.1 No.3.

Bank BTN, "Tentang Kami”, Budaya kerja nilai-nilai budaya perusahaan. https://www.btn.co.id/id/Tentang-

Kami [diakses pada 19 september 2019].

Bintoro dan Daryanto (2017). Manajemen Penilaian Kinerja Karyawan. Yogyakarta: Gava Media.

Fauzi, M. (2016). Pengaruh Budaya Organisasi dan Kepuasan Kerja Terhadap Kinerja Karyawan dengan Komitmen Organisasi sebagai Variabel Intervening. Semarang). Journal of management, Vol.02 No.02.

Ganyang, M.T. (2018). Manajemen Sumber Daya Manusia. Bogor: IN MEDIA.

Mulyadi, D. , Sulaeman, E. Dan Ramdhani, A. (2017). Pengaruh Budaya Organisasi Terhadap Kinerja Pegawai Pada Dinas Bina Marga dan Pengairan Kabupaten Karawang. Karawang). Journal Manajemen, Vol.09 No.04.

Marta, J.D (2016). Pengaruh Budaya Organisasi dan Komunikasi Terhadap Kinerja Karyawan PT.X. Surabaya). Bisnis dan Manajemen, Vol.08 No.02

Renyut, C.L. (2017). ). Pengaruh Budaya Organisasi dan Lingkungan kerja terhadap kinerja pegawai. Samarinda). Jurnal Skripsi Universitas Telkom.

Rijanto, A dan Mukaram (2018). Pengaruh Budaya Organisasi Terhadap Kinerja Karyawan (Studi di Divisi Account Executive PT. Agrodana Futres). Bandung). Jurnal riset bisnis dan investasi.

Sedarmayanti (2018). Manajemen Sumber Daya Manusia. Bandung: PT. Refika Aditama.

Siregar, S. (2017). Metodologi Penelitian Kuantitatif, Jakarta: PT. Fajar Interpratama Mandiri.

Sujarweni (2018). Metodologi Penelitian. Yogyakarta: Pustaka baru press.

Sulistiawan, D. (2017). Pengaruh Budaya Organisasi terhadap kinerja karyawan divisi penyamakan kulit PT. Adi satria abadi Yogyakarta). Jurnal Kinerja, Vol.14 No.2.
Torang, S. (2016). Organisasi \& Manajemen. Bandung: Alfabeta.

Uha, I.N. (2017). Budaya Organisasi Kepemimpinan dan Kinerja. Depok: Kencana. 